INTERNATIONAL JOURNAL OF RESEARCHES IN BIOSCIENCES, AGRICULTURE AND TECHNOLOGY

(C) VISHWASHANTI MULTIPURPOSE SOCIETY (Global Peace Multipurpose Society) R. No. MH-659/13(N) www.vmsindia.org

\title{
PHYSICO-CHEMICAL ANALYSIS OF BOREWELLS OF SELECTED VILLAGES OF ETAPALLI TALUKA, DISTRICT GADCHIROLI (M.S.)
}

\author{
S. B. Rewatkar, M. I. M. Siddique ${ }^{1}$, A. R. Gourkar' ${ }^{2}$, Y. B. Meshram ${ }^{3}$ and \\ G. R. Nimbarte ${ }^{4}$ \\ Mohsinbhai Zaweri College, Desaiganj (Wadsa), Dist- Gadchiroli; (M.S.) \\ ${ }^{1}$ Government Science College, Gadchiroli (M.S.) \\ ${ }^{2}$ Shivaji Science College, Gadchiroli. (M.S.) \\ ${ }^{3}$ G.S. Science College Khamgaon, District Buldhana. (M.S.) \\ ${ }^{4}$ M.K.B. Science College, Gadchiroli. (M.S) \\ avi.gaurkar@gmail.com
}

\begin{abstract}
:
Physico-chemical analysis such as $\mathrm{pH}$, electrical conductivity (EC), total dissolved solids (TDS), total hardness $(\mathrm{TH})$, chloride $\left(\mathrm{Cl}^{-}\right)$, nitrate $\left(\mathrm{NO}^{-}\right)$, iron $(\mathrm{Fe})$ and fluoride $\left(\mathrm{F}^{-}\right)$of borewell water of selected villages Etapalli taluka, district Gadchiroli (M.S.) Was carried out during January 2015 to assess the quality of borewell water. After the analysis of different physico-chemical parameters (using Indian standards), the suitability of ground water for drinking and domestic purposes could be ascertained. Borewell water samples collected from the villages Kudri tola, Langi, Tadguda and Geratola were found to be under threat due to high iron and fluoride concentration. TDS at Langi and Kondawahi village were found higher than recommended limit. Nitrate concentration was also found at higher level at Geratola village. Therefore it is recommended to take the drinking water issue at higher public health concern.

Keywords : Physico-chemical analysis, drinking water, borewells of selected villages, Etapalli taluka, Gadchiroli
\end{abstract} district.

\section{Introduction:}

Water is prerequisite of life and thus life without it is impossible. It is the basic need of living organisms as well as plants. Though it is a precious gift of nature it has been mishandled and misused through anthropogenic activities so that it has become the potential danger to human health and existence. Ground water sources often necessitate examination of water samples from different points and under varying conditions to find out the extent of pollution and purification that taken place in ground water. ${ }^{1-2}$

Being a basic need of human development, health and well-being, safe drinking water is an internationally accepted human right ${ }^{3}$, which has been enlisted as one of the ten targets in the Millenium Development Goals (MDGs).In continuation with earlier studies of water quality assessment, present attempt is made to analyze the physico-chemical parameters of ten borewell water samples of different villages of Etapalli taluka, District Gadchiroli (M.S.), in order to assess the suitability of water for drinking and domestic purpose.

\section{Study Area:}

Etapalli is a taluka of Aheri subdivision of Gadchiroli district along with Aheri, Bhamaragad and Sironcha taluka. It is about $135 \mathrm{~km}$ away from district headquarter Gadchiroli. It is on the latitude 18.982 and longitude 80.034. According to census 2011, there are about 180 villages in Etapalli taluka. People mostly depend on agriculture.

\section{Materials and Methods:}

(i) Sampling and collection of water samples The present attempt was an effort to assess the borewell water quality of different villages of Etapalli taluka, District Gadchiroli (M.S.). Water samples were collected from different borewell sites at $9.00 \mathrm{am}$ to $11.00 \mathrm{am}$ in the first week of January 2015 and analyzed for physicochemical parameters. The water samples were collected in polythene bottles of two litre capacity, which were cleaned with acidulated water, followed by rinsing twice with distilled water. The sampling sites are given in the Table- 1 .

\section{(ii) Methodology}

To examine water quality of ten water samples, major water quality physico-chemical parameters considered are $\mathrm{pH}, \mathrm{EC}, \mathrm{TDS}, \mathrm{DO}, \mathrm{TH}$, $\mathrm{Cl}^{-}, \mathrm{NO}^{-}, \mathrm{Fe}$ and $\mathrm{F}^{-}$. ${ }^{4}$

$\mathrm{pH}, \mathrm{EC}, \mathrm{DO}$ and TDS were determined by using $\mathrm{pH}$ meter, EC scan meter, conductometer and TDS meter respectively. TH was measured by EDTA titration method. ${ }^{5}$ Nitrate was observed by phenol dysphonic acid method ${ }^{6}$. Fluoride content in water was measured by ELICO- 52 spectro photometer. Thus physico-chemical analysis was carried out according to standard methods. ${ }^{7-9}$

\section{Results and Discussion:}

The average results of the physicochemical parameters for water samples are presented in table 2. The quality of borewell water has been assessed by comparing each parameter with the standard desirable limit of 
that parameter in drinking water as prescribed by ISI $10500-91$.

pH

$\mathrm{pH}$ is a term used universally to express the intensity of the acidic or alkaline condition of a solution. $\mathrm{pH}$ is an important parameter of water since most of the aquatic organisms are adapted to average $\mathrm{pH}$ and do not withstand abrupt changes. ${ }^{10}$ The $\mathrm{pH}$ value of water samples varied between 7.6 to 8.3 and were found within the limit prescribed by ISI.

\section{Electrical conductivity (EC)}

Electrical conductivity is a measure of water capacity to convey electric current. It signifies the amount of total dissolved salts. ${ }^{11^{112}}$. Present investigation reported EC values in the range of $321 \mu \mathrm{s} . \mathrm{cm}^{-1}$. High EC values were observed for E10 (Kondawahi village) indicating the presence of high amount of dissolved inorganic compounds in ionized form.

\section{Total dissolved solids (TDS)}

Total dissolved solids reflects the salinity behaviour of ground water. Water containg more than $500 \mathrm{mg} / 1$ of TDS is undesirable for drinking water according to Indian Standards but in unavoidable circumstances $1500 \mathrm{mg} / 1$ is also allowed. ${ }^{13}$. TDS values varied from $205 \mathrm{mg} / \mathrm{L}$ to $673 \mathrm{mg} / \mathrm{L}$. The water samples E2 and E10 showed higher TDS values than the prescribed limit given by ISI.

\section{Dissolved oxygen (DO)}

Dissolved oxygen is an important parameter in water quality assessment and reflects the physical and biological processes prevailing in the water. The DO value indicate the degree of pollution in water bodies. Present study showed the DO content of water ranging between $3.9 \mathrm{mg} / \mathrm{L}$ to $5.6 \mathrm{mg} / \mathrm{L}$. Thus DO level in borewell water samples was well within the prescribed limit.

\section{Total hardness (TH)}

Hardness is the property of water which prevents the lather formation with soap and increases the boiling point of water. ${ }^{14}$. It mainly depends on calcium and / or magnesium salt presents in water. The total hardness ranged between $158 \mathrm{mg} / \mathrm{L}$ to $423 \mathrm{mg} / \mathrm{L}$. The water samples E2 and E10 showed higher TH values than the prescribed limit.

\section{Chloride $\left(\mathrm{Cl}^{-}\right)$}

The chloride concentration serves as indicator of pollution by sewage. People accustomed to higher chloride in water are subjected to laxative effects. ${ }^{11}$. Chloride may be present naturally in ground water and may also originate from diverse source such as weathering, leaching of sedimentary rocks and infiltration of sea water etc.

In the present investigation chloride concentration of water samples was found to be in the range of $20 \mathrm{mg} / \mathrm{L}$ to $172 \mathrm{mg} / \mathrm{L}$. samples were thus well within the prescribed limit of ISI.

\section{Nitrate ( $\left.\mathrm{NO3}^{-}\right)$}

Ground water contains nitrate due to leaching of nitrate with the percolating water. Sewage and wastes rich in nitrate can also add to the concentration of water. The present investigation revealed the range of nitrate between $1 \mathrm{mg} / 1$ to $156 \mathrm{mg} / 1$ thereby showing the higher nitrate concentration in water in sample E8.

Iron (Fe)

The present study recorded the iron concentration in water samples varying between $0.21 \mathrm{mg} / \mathrm{L}$ to $0.86 \mathrm{mg} / \mathrm{L}$. Water samples E1 and E2 showed higher iron concentration which exceeded the limit prescribed by ISI.

\section{Fluoride ( $\mathrm{F}^{-}$)}

The present investigation showed the fluoride concentration of borewell water samples ranging between $0.32 \mathrm{mg} / \mathrm{L}$ to $2.0 \mathrm{mg} / \mathrm{L}$. The water samples E2 and E7 exhibited higher fluoride concentration beyond the prescribed limit of ISI, showing fluorotic villages though less endemic in the block. Phosphate fertilizers and fluoride minerals present in soil undergo dissolution due to heavy rainfall during monsoon seasons and thus probably increase the fluoride levels in water sources. ${ }^{15^{-16}}$.

\section{Table 1}

\begin{tabular}{|l|l|l|l|}
\hline Sr No & Sample Number & Sampling sites (village) & Place \\
\hline 1 & E1 & Kudri tola & Near house of Kesari Peka Duga \\
\hline 2 & E2 & Langi & Near house of Chandrawati Vikas \\
\hline 3 & E3 & Zarewada & Near house of Shankhar Kalidas Tobha \\
\hline 4 & E4 & Tambda & Near house of Butka Dashru Katlami \\
\hline 5 & E5 & Halewara tola & Near house of Peka Govinda Halami \\
\hline 6 & E6 & Venasar & Near house of Kailash Ramji Palko \\
\hline 7 & E7 & Tadguda & Near house of Manu Buddha Bade \\
\hline 8 & E8 & Geratola & Near house of Soma Madavi \\
\hline 9 & E9 & Pidiguddam & Near house of Gajanan Gundalwar \\
\hline 10 & E10 & Kondawahi & Near house of Chatu Kumeri \\
\hline
\end{tabular}


Table 2 : Water quality assessment of borewell water samples from ten sampling sites (E1 - E10) in Etapalli taluka, district Gadchiroli (M.S.)

\begin{tabular}{|c|c|c|c|c|c|c|c|c|c|c|}
\hline Sr No & water samples & \multicolumn{10}{|c|}{ Parameters } \\
\hline & & $\mathrm{pH}$ & $\mathrm{EC}$ & $\mathrm{TDS}$ & $\mathrm{DO}$ & $\mathrm{TH}$ & $\mathrm{Cl}^{-}$ & $\mathrm{NO}^{-}$ & $\mathrm{Fe}$ & $\mathrm{F}^{-}$ \\
\hline 1 & E1 & 8.1 & 496 & 317 & 4.3 & 204 & 52 & 18 & 0.32 & 2.0 \\
\hline 2 & E2 & 7.8 & 929 & 595 & 5.6 & 301 & 88 & 44 & 0.86 & 1.4 \\
\hline 3 & E3 & 7.6 & 409 & 262 & 5.1 & 158 & 34 & 18 & 0.28 & 0.47 \\
\hline 4 & E4 & 8.2 & 482 & 308 & 3.9 & 186 & 68 & 06 & 0.21 & 0.32 \\
\hline 5 & E5 & 8.3 & 480 & 307 & 5.6 & 206 & 50 & 39 & 0.29 & 0.57 \\
\hline 6 & E6 & 7.6 & 330 & 211 & 4.7 & 210 & 28 & 26 & 0.26 & 0.87 \\
\hline 7 & E7 & 8.3 & 321 & 205 & 5.2 & 204 & 20 & 01 & 0.28 & 1.92 \\
\hline 8 & E8 & 7.6 & 468 & 300 & 5.1 & 252 & 68 & 156 & 0.30 & 0.48 \\
\hline 9 & E9 & 7.9 & 363 & 232 & 5.2 & 208 & 34 & 27 & 0.28 & 0.83 \\
\hline 10 & E10 & 8.1 & 1052 & 673 & 4.2 & 423 & 172 & 39 & 0.25 & 0.56 \\
\hline
\end{tabular}

\begin{tabular}{|l|l|l|l|l|l|l|l|l|l|}
\hline & $\mathrm{pH}$ & $\mathrm{EC}$ & $\mathrm{TDS}$ & $\mathrm{DO}$ & $\mathrm{TH}$ & $\mathrm{Cl}^{-}$ & $\mathrm{NO}^{-}$ & $\mathrm{Fe}$ & $\mathrm{F}^{-}$ \\
\hline Minimum value & 7.6 & 321 & 205 & 3.9 & 158 & 20 & 1 & 0.21 & 0.32 \\
\hline Maximum value & 8.3 & 1052 & 673 & 5.6 & 423 & 172 & 156 & 0.86 & 2.0 \\
\hline ISI (10500-91) & $6.5-8.5$ & - & 500 & 5.0 & 300 & 250 & 45 & 0.3 & 1.0 \\
\hline
\end{tabular}

*All parameters are in $\mathrm{mg} / \mathrm{L}$ except $\mathrm{pH}$ and EC. EC is in $\mu \mathrm{s} . \mathrm{cm}^{-1}$.

pH
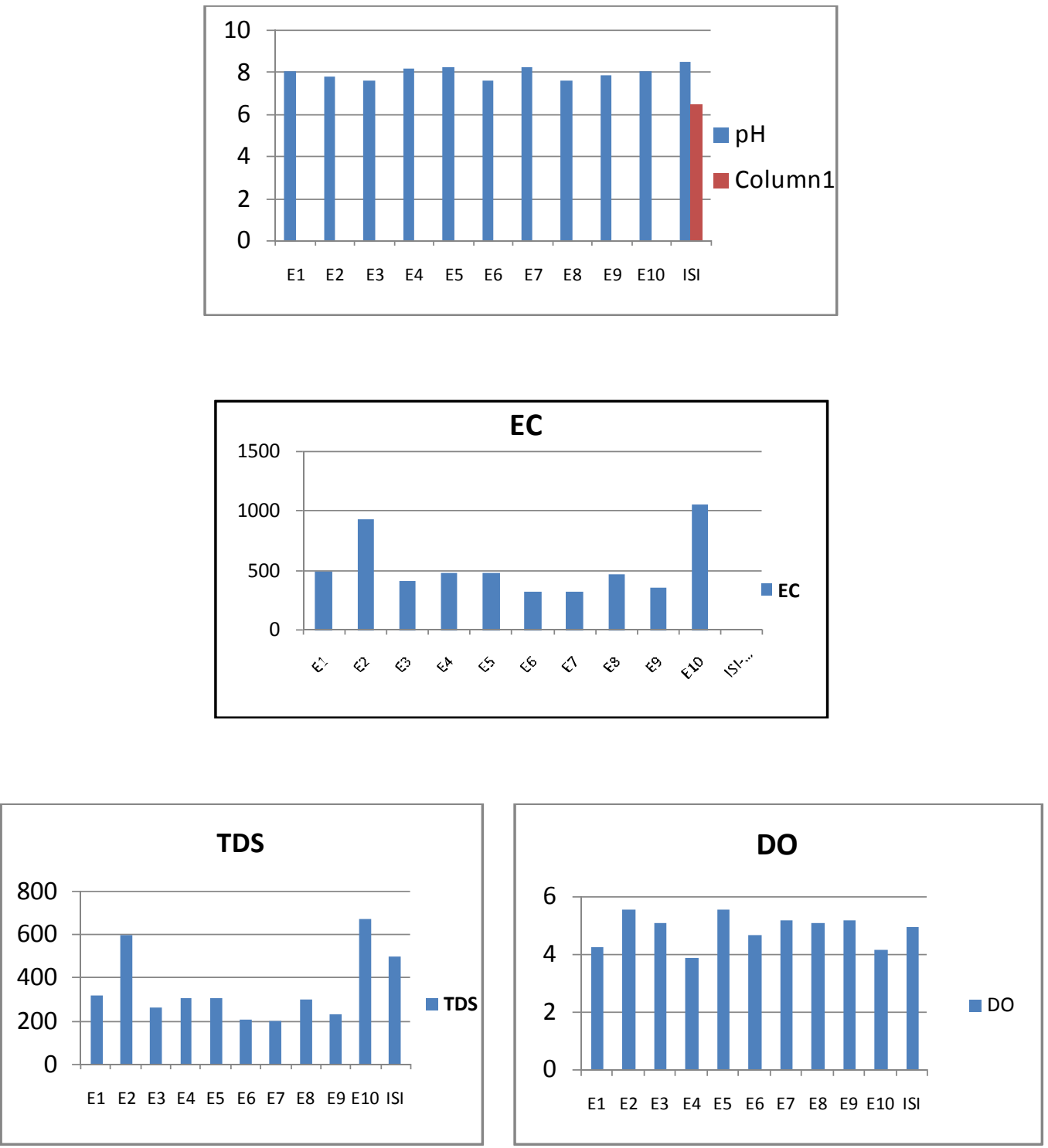

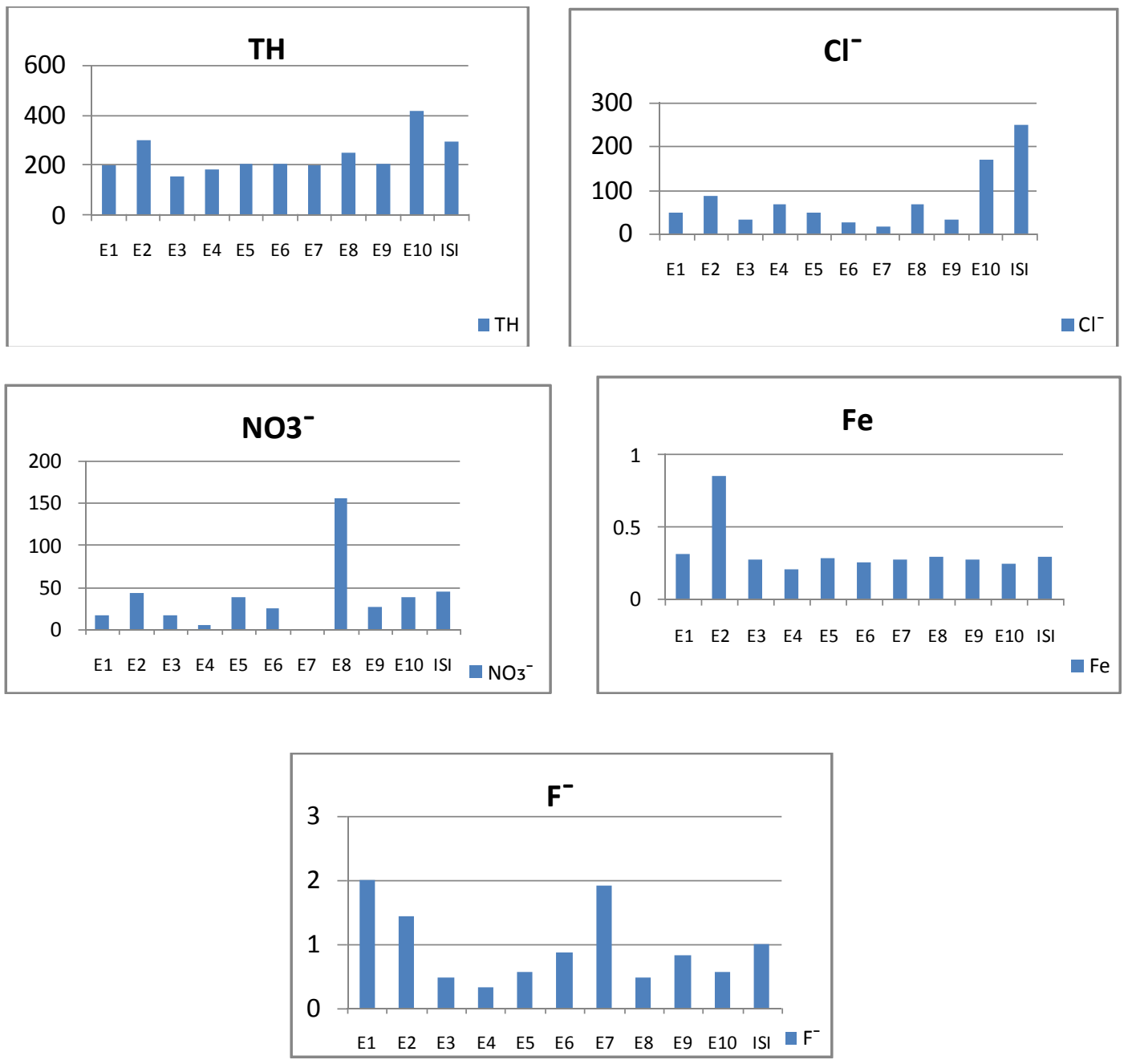

Figure: 1 Figures showing physico-chemical parameters of Borewell water samples of selected villages of Etapalli taluka, district Gadchiroli (M.S.).

\section{Conclusion}

In general ground water quality of most of the water samples of different villages of Etapalli block is under threat due to high iron and fluoride concentration.

TDS at E2 (Langi) and E10 (Kondawahi) villages were found higher by surpassing the prescribed limits of drinking water. EC was found to be the highest at E10 (Kondawahi).

Nitrate concentration in water samples was beyond the prescribed limit in E8 sample (Geratolla village) showing water contamination possibly due to improper sewage and waste disposal.

It is evident from the values of parameters of iron and fluoride that Etapalli block having villages Kudritola, Langi and Tadguda are iron and fluoride prone where borewell water is unfit to drink. Borewell water sources of these villages are certainly polluted due to dissolution of iron and fluoride minerals in water. Therefore underground water needs a regular monitoring and treatment before consumption.

\section{References}

1. Abdul Jameel A, Poll. Res. 1998, 17 (2), 114-119.

2. Sirkar A.G et al, JIWWA, 1996, Oct. Dec. 1996, 215-220.

3. WHO (2001), "water health and human rights", world water day, http: / / www.worldwaterday.org/thematic (hmn rights.html\# $\mathrm{n}_{4}$ )

4. Mitra A. and Gupta S.K, J. Indian soc. Soil sci, 1999, G7, 99-105.

5. B.K. Handa, Hydrochemical Zones of India, Pro. Seminar on ground water development, Roorkee, 339-450, 1986.

6. Saigal Rafat Imam, Ph.D thesis, VKSU, Arn (2010). 
6. APHA, 19th Edition, American Public Health Association, Washington

, D.C. (1995).

7. Mayur C. Shaha, Poll. Res., 25 (3), 549 (2006).

8. B. Kotaiah, N. Kumarswamy, Environmental Engineering Lab, Manual, $5^{\text {th }}$ edition, Charotar publishing House, India (1994).

9. George J.P. 1997, Aquatic ecosystem, structure, degradation strategies for management in recent advances in ecobiological research, A.P.H Publication House, New Delhi, 603.

10. Sudhir Dahiya and Amarjeet Kaur, Physico-chemical characterstics of underground water in rural areas of Tosham subdivision, Bhivani district, Haryana, J.Environ Poll, 1999, 6(4), 281.
11. Pandian,S., Revathy, V., Sheela, V.v, Shyamala, A, Quality of revier and reservier water of Tamiul Nadu proc. Seminar on water quality and its management, central board of irrigation power, New Delhi (1995), 91-95.

12. Shrinivasa Rao $B$ and Venkateswarala $\mathbf{P}$, physico-chemical Analysis of selected Ground water samples, Indian J. Environ Prot., 2000, 20 (3), 161.

13. Trivedy R.K. and Goel P.K, Chemical and Biological methods for water pollution studies, Environmental Pollution, Korad, 1986.

14. B.Rao, Nagemalleswar, S.V.R Rao and G.V.V.S Chaudary, Ind. Journal, Env. Protection, 10(5), 1990, 160-162.

15. V.K Saxena and S. Ahmed, Inferring the chemical parameters for the dissolution of fluoride in ground water, Environmental Geology, 43, 2003, 731-736. 